\title{
Lean Management jako koncepcja zrównoważonych tańcuchów dostaw
}

http://dx.doi.org/10.18778/8142-085-3.07

\author{
Agnieszka Wójcik, Dominik Wronkowski \\ Studenckie Koło Naukowe Logistyki i Innowacji LOGIN \\ Wydział Ekonomiczno-Socjologiczny, Uniwersytet Łódzki
}

\section{Wstęp}

Lean Management to metoda zarządzania przedsiębiorstwem zmierzająca do ciągłego doskonalenia procesów w nim zachodzących. Wyszczupleniu może podlegać cała struktura zrównoważonego łańcucha dostaw. Zastosowanie narzędzi Lean Management ma miejsce w fazie zaopatrzenia, produkcji, dystrybucji, a także realizacji zwrotów. Skupiając się na eliminacji przejawów marnotrawstwa w przedsiębiorstwach, które odpowiadają za realizację procesów zaopatrzenia i produkcji, można dostrzec, jak wymierne korzyści przynosi wprowadzenie szczupłego zarządzania dla każdego z uczestników przepływów materiałowych.

\section{Istota Lean Management i zrównoważonych tańcuchów dostaw}

\subsection{Lean Management}

Lean Management to filozofia opierająca się na zbiorze technik i zasad zarządzania, które mają doprowadzić do podniesienia jakości oferowanych dóbr i usług oraz zwiększania zysków przedsiębiorstwa, przy jednoczesnej redukcji czasu i kosztów poniesionych podczas realizacji procesów. Istotnym elementem filozofii Lean jest eliminacja wszystkich typów marnotrawstwa, a co za tym idzie poprawienie efektywności firm współpracujących ze sobą w łańcuchu dostaw.

Narzędzi Lean po raz pierwszy użyto w fabryce Toyoty. Zwiększono możliwości produkcyjne w taki sposób, aby otrzymać większą ilość produktów przy zaan- 
gażowaniu minimum nakładów. W efekcie nauczono się gospodarować zasobami w sposób bardziej efektywny.

Fundamentalną zasadą szczupłego zarządzania jest przedstawienie finalnemu odbiorcy dokładnie takiego produktu, jakiego oczekuje. Oferowane dobro powinno być pozbawione jakichkolwiek uszkodzeń i defektów oraz dostarczone w odpowiednim czasie i po jak najniższych kosztach.

\subsection{Zrównoważony tańcuch dostaw}

Zrównoważony łańcuch dostaw to taki, w którym przedmiotem zainteresowania nie jest jedynie przepływ dóbr i usług oraz informacji i pieniędzy pomiędzy jego kolejnymi ogniwani. Należy też uwzględnić cały cykl życia produktu, a także oddziaływanie systemu na społeczeństwo, gospodarkę i środowisko (zob. rys. 1). Wszystkie podjęte w myśl zasad Lean Management działania mają na celu oszczędzanie zasobów i zwiększenie dochodu przedsiębiorstw. Nadrzędnym celem tej filozofii jest jednak budowanie dobrych relacji pomiędzy dostawcami i odbiorcami oraz podnoszenie satysfakcji klientów.

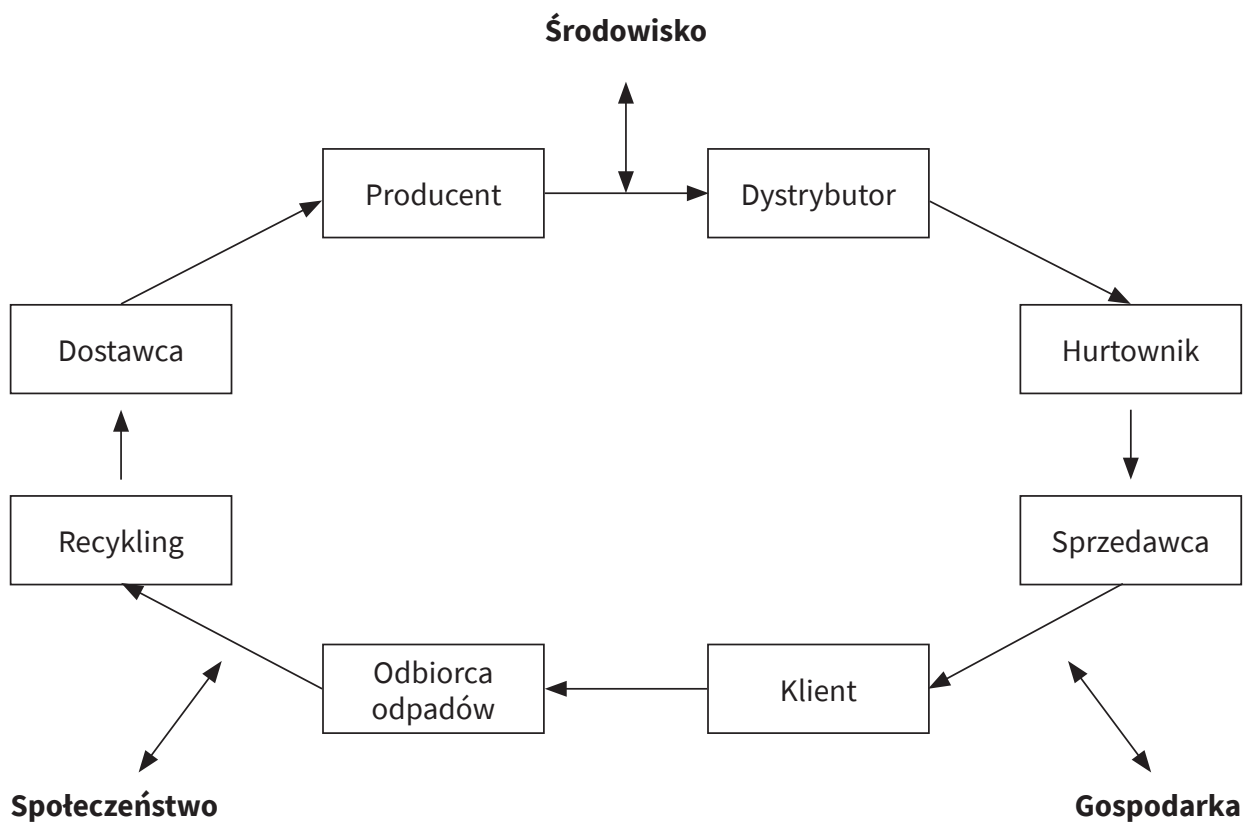

Rysunek 1. Zrównoważony łańcuch dostaw

Źródło: opracowanie własne na podstawie http://odpowiedzialnybiznes.pl/publikacje/analizatematyczna-zrownowazony-lancuch-dostaw-trendy-i-innowacje/ [dostęp 11.03.2016]. 
Firmy tworzące łańcuch dostaw powinny przyczyniać się do poprawy dobrobytu społecznego i stanu środowiska. Biorąc pod uwagę kryteria społeczne, powinno się zarządzać siecią dostaw w taki sposób, aby nie łamać praw człowieka, zaprzestawać wszelkich przejawów dyskryminacji i respektować wymogi sanitarne. Opierając się na kryteriach ekonomicznych, należy zapobiegać korupcji, przestrzegać kontraktów i terminowo regulować wszystkie należności. Kryterium środowiskowe odnosi się do minimalizowania i likwidacji wszystkich negatywnych oddziaływań na środowisko naturalne.

\section{Lean Management w zrównoważonym tańcuchu dostaw}

\subsection{Zastosowanie Lean Management w zrównoważonym tańcuchu dostaw}

Wykorzystanie Lean Management jako filozofii zarządzania przedsiębiorstwami wchodzącymi w skład zrównoważonego łańcucha dostaw pozwala na zawiązanie długofalowej współpracy między nimi i kreowanie wspólnego sukcesu, jakim jest budzenie zadowolenia wśród finalnych odbiorców dóbr i usług świadczonych przez te firmy. Istotnym elementem w procesie budowania współpracy jest prawidłowy przepływ informacji pomiędzy ogniwami sieci dostaw, niwelacja ponoszonych kosztów i czasu, a także nieustanne harmonizowanie działań. Organizacja, jaką jest zrównoważony łańcuch dostaw, powinna nieustannie rozwijać się pod względem technologicznym, aby systematycznie budować swoją przewagę konkurencyjną na rynku. Poza współpracą, fundamentalną kwestią zarządzania zrównoważonym łańcuchem dostaw jest eliminacja marnotrawstwa (jap. muda). Wyróżniamy osiem typów marnotrawstwa, są to: nadprodukcja, zbędny ruch, oczekiwanie, zbędny transport, wady i usterki, nadmierne zapasy, nadmierne przetwarzanie oraz niewykorzystanie potencjału pracowników.

\subsection{Funkcjonowanie zrównoważonego tańcucha dostaw w oparciu o zasady Lean Management}

Proces wdrażania koncepcji Lean w zrównoważonym łańcuchu dostaw składa się z czterech powiązanych ze sobą procesów (zob. rys. 2), które podlegają ciągłym pomiarom efektywności. 


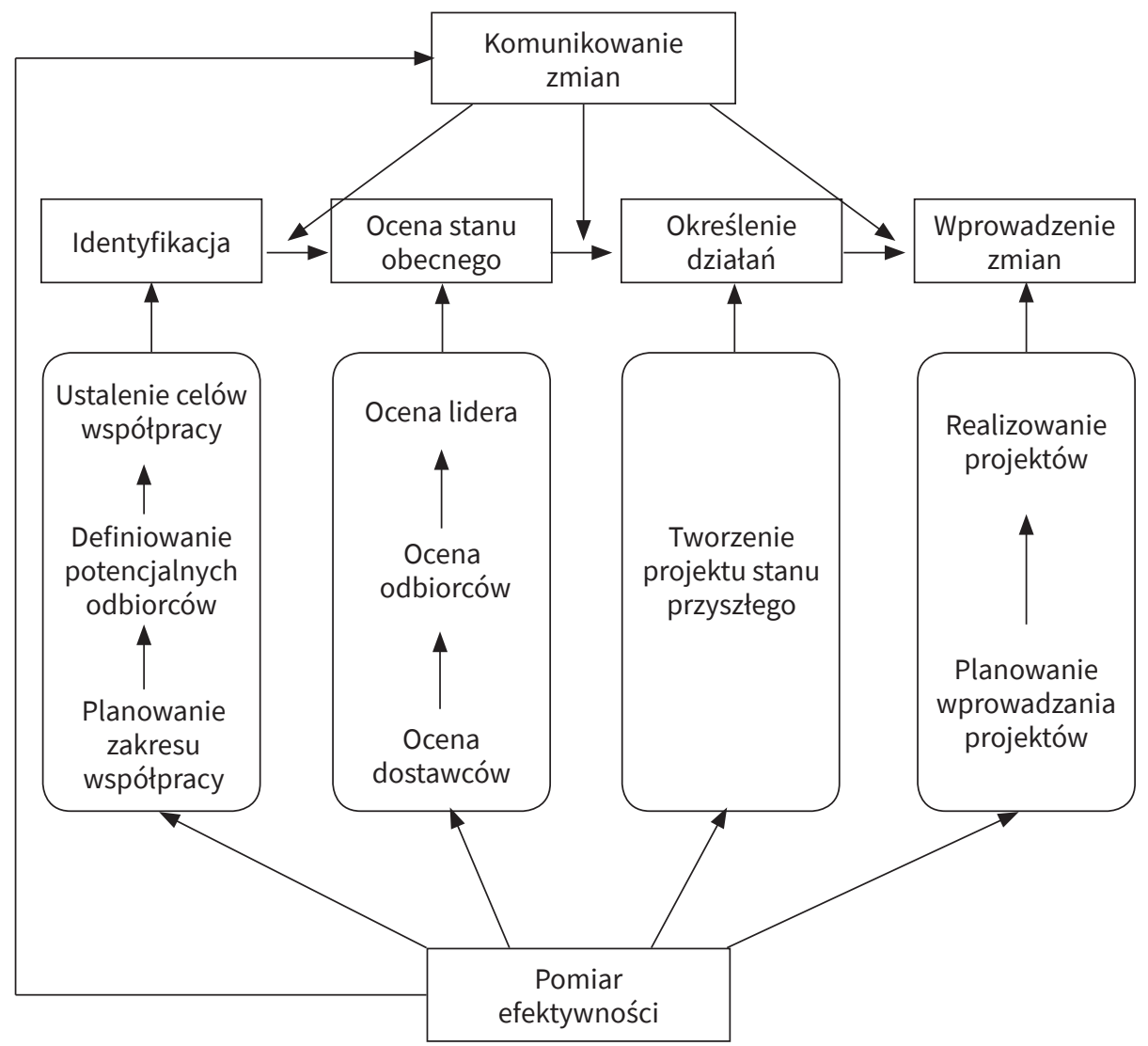

Rysunek 2. Etapy wdrażania koncepcji Lean w zrównoważonym łańcuchu dostaw

Źródło: opracowanie własne na podstawie http://www.czasopismologistyka.pl/artykulynaukowe/send/-/67 [dostęp 28.03.2015].

Funkcjonowanie zgodnie z zasadami Lean Management opiera się na pięciu głównych zasadach tej filozofii:

- System ssący (rys. 3) - polega na projektowaniu łańcucha dostaw w taki sposób, że system logistyczny tworzony jest w momencie pojawienia się na rynku popytu na dane towary lub usługi. Podstawą prawidłowego działania tego systemu jest perfekcyjny przepływ informacji pomiędzy ogniwami łańcucha dostaw.

- Zdefiniowanie wartości - wraz z przechodzeniem produktu przez kolejne fazy łańcucha dostaw zwiększana jest jego wartość. Produkt poddawany jest obróbce, następnie pakuje się go oraz zabezpiecza. Czynności te pochłaniają koszty, przyczyniając się równocześnie do zwiększenia wartości produktu, która jest określana przez klientów. 
- Określenie strumienia wartości - polega na zaplanowaniu szeregu procesów, które następują po sobie w celu nadania produktowi wartości oczekiwanej na rynku zbytu.

- Organizacja przepływu - czyli wprawienie w ruch planowanych procesów i dążenie do ich harmonizacji.

- Doskonalenie - rozumiane jako systematyczne eliminowanie przejawów marnotrawstwa.

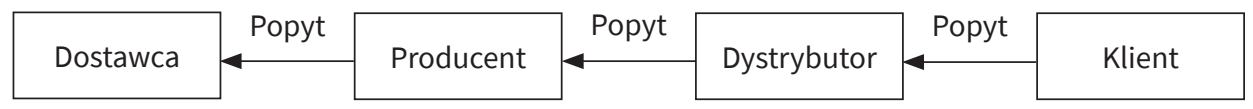

Rysunek 3. System ssący w tańcuchu dostaw

Źródło: opracowanie własne na podstawie Harrison, van Hoek, 2010: 261.

Przedsiębiorstwa wchodzące w skład zrównoważonego łańcucha dostaw powinny również zwracać uwagę na relacje $\mathrm{z}$ otoczeniem społecznym, gospodarczym i przyrodniczym, tak by eliminować przejawy szkodliwego oddziaływania na środowisko, w którym funkcjonują.

\section{Eliminacja przejawów marnotrawstwa w zrównoważonym tańcuchu dostaw}

\subsection{Logistyka zaopatrzenia}

Logistyka zaopatrzenia, jako jedna z głównych gałęzi logistyki, jest kluczowym elementem łańcucha dostaw. Do jej zadań należą sterowanie zapasami, planowanie potrzeb materiałowych, wybór źródeł zakupu i organizacja dostaw. Zaopatrzenie musi odpowiedzieć na zapotrzebowania na dane materiały. Pytania, które stawia sobie ten dział logistyki, to gdzie i kiedy należy dostarczyć oferowane przez daną sieć dostaw dobro? Należy też dokonać wyboru źródła transportu i zapoznać się z warunkami zamówienia i reklamacji. W zarządzaniu procesem zaopatrzenia istotne jest zapoznanie się z kosztami (zob. rys. 4), które mu towarzyszą. W celu obniżenia kosztów zakupów można prowadzić negocjacje dotyczące ceny, pozwala to na zaoszczędzenie funduszy przez przedsiębiorstwo, przy jednoczesnym utrzymaniu jakości kupowanego produktu. 


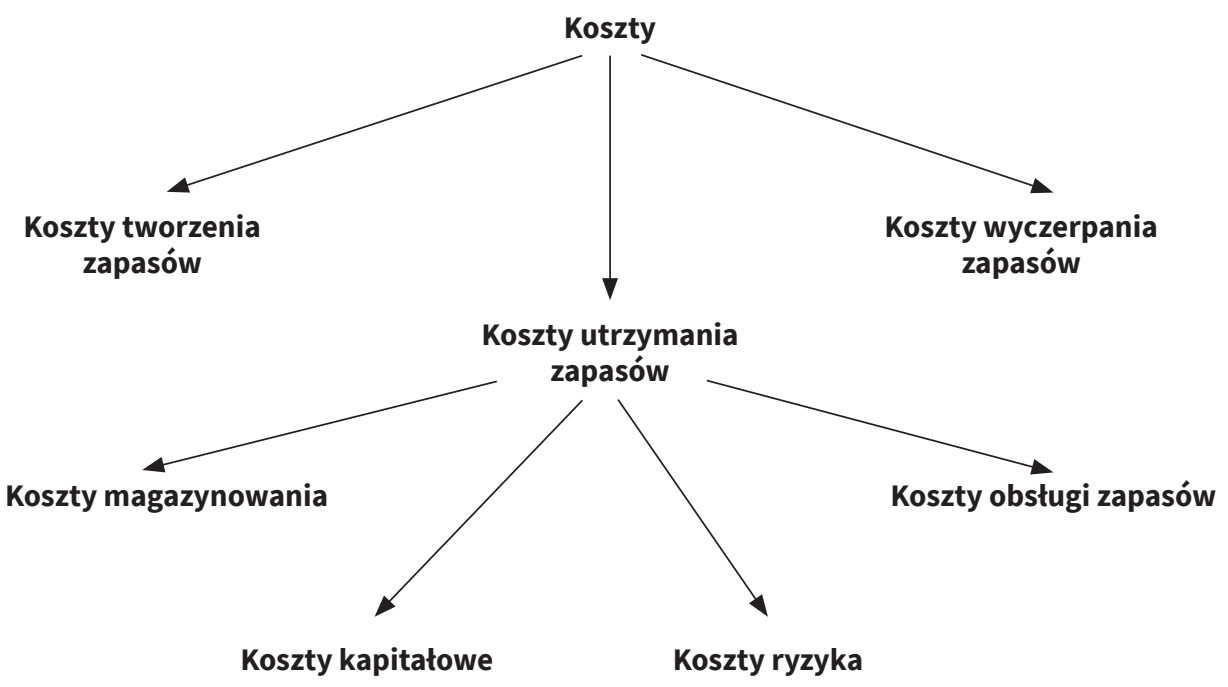

Rysunek 4. Podstawowe kategorie kosztów zaopatrzenia

Źródło: opracowanie własne na podstawie Golińska, 2012: 251.

W celu optymalizacji procesu zaopatrzenia należy utrzymywać jak najmniejszy możliwy poziom zapasów, wiąże się to $\mathrm{z}$ eliminacją jednego z głównych typów marnotrawstwa (nadmiernych zapasów). Zbyt wysoki poziom surowców, półproduktów czy materiałów w magazynie generuje niepotrzebne koszty. Kolejnym ważnym elementem zaopatrzenia jest dokonywanie racjonalnych zakupów i precyzyjny czas ich dostawy. Elementy te są istotne $z$ punktu widzenia czasu, jaki generują wszelkie opóźnienia w procesie zakupów. Warto wspomnieć, że nie zawsze najniższy koszt zakupów przekłada się na minimalizację kosztów w całym łańcuchu dostaw. Materiały o niższym koszcie zazwyczaj charakteryzują się niższą jakością, co może powodować usterki w kolejnych etapach przepływu. Wady to kolejny typ marnotrawstwa, więc należy eliminować wszelkie usterki i ich przyczyny. Wadliwy produkt trzeba poddać naprawie, to z kolei tworzy koszty, których należy unikać.

Komunikacja i współpraca decydują o tym, czy łańcuch dostaw jest w stanie działać sprawnie i efektywnie. Ogniwa odpowiedzialne za proces zakupów muszą współdziałać z działami marketingu i sprzedaży. Od nich otrzymują informacje o zgłaszanym przez rynek popycie. Komunikacja jest w tym przypadku bardzo istotna, przekazanie błędnej lub niepełnej informacji może przyczynić się do wygenerowania zbyt dużego poziomu zapasów lub zakupienia niewystarczającej ilości surowców potrzebnych do produkcji. Komunikacja z działem produkcji 
wynika z bezpośredniej współpracy tych ogniw w realizacji celu logistyki. Bez odpowiedniego poziomu dostarczonych materiałów, surowców, modułów i półproduktów, proces produkcji nie może odbyć się w sposób w pełni efektywny. Dobry przepływ informacji między wspomnianymi działami jest ważny ze względu na fakt, iż dostawy planowane, po uwzględnieniu potrzeb produkcji, są zharmonizowane z procesami zachodzącymi w sieci dostaw. Wprowadzając metodę Lean do zarządzania łańcuchem dostaw, należy starannie dobierać dostawców i poddawać świadczone przez nich usługi okresowej kontroli. Szczupłe zarządzanie w zamyśle ma za zadanie stworzyć i podtrzymywać dobre relacje pomiędzy współpracującymi firmami.

\subsection{Logistyka produkcji}

Decyzja Make Or Buy jest jednym z filarów efektywnego działania łańcucha dostaw. Ta strategiczna decyzja musi być podjęta już w trakcie planowania sieci dostaw. Można ją interpretować na dwa sposoby, pewien produkt można wytworzyć lub kupić, należy więc zastanowić się, która z decyzji będzie bardziej opłacalna dla przedsiębiorstwa. Decyzja ta znajduje również odzwierciedlenie w przypadku, gdy należy się zastanowić, czy daną firmę wykupić czy nawiązać z nią współpracę. Podjęcie właściwej decyzji przynosi korzyści dla wszystkich przedsiębiorstw współpracujących przy przepływie dóbr i usług do finalnego odbiorcy.

Wymagania klientów stają się coraz bardziej złożone i sprecyzowane, natomiast proces produkcji jest bardzo skomplikowany i często złożony z wielu etapów. Jeśli proces ten nie zachodzi w sposób harmonijny i jest źle skoordynowany z pozostałymi ogniwami łańcucha dostaw, powoduje opóźnienia i koszty, które przekładają się na zmniejszenie jakości oferowanej finalnemu odbiorcy. W celu optymalizacji procesu produkcji i całej sieci przepływów dóbr i usług, kierownictwo przedsiębiorstwa powinno korzystać ze „szczupłego zarządzania” i wprowadzić zmiany w jego strukturze i zasadach działania, co w efekcie pozwoli na zwiększenie efektywności zachodzących w nim procesów. Kluczem do podnoszenia jakości i sprawności działania zakładu produkcyjnego jest eliminowanie marnotrawstwa. Zmiany w funkcjonowaniu należy zacząć od konstruktywnej i obiektywnej oceny i analizy działania firmy, a potem przystąpić do usprawnienia i dokonania korekt.

Udoskonaleniu należy poddać cały proces produkcji, korygując wszystkie jego elementy. Aby osiągnąć zamierzone efekty, należy między innymi ustalić optymalną wielkość produkcji. Nadprodukcja, będąca jednym z typów marnotrawstwa, generuje zapasy. Zbyt wysoki poziom produktów w magazynie jest również marnotrawstwem. Kolejnym przykładem marnotrawstwa są wady, które pojawiają się w procesie produkcji. Wytworzenie produktu niespełniającego norm jakości generuje koszty, ponieważ taki produkt trzeba zutylizować lub przetworzyć. Nad- 
mierne przetwarzanie również jest niepożądane w procesie produkcji i funkcjonowaniu łańcucha dostaw, jest więc także zaliczane do głównych typów marnotrawstwa. Dokonując zmian w przedsiębiorstwie, aby dostosować je do wymogów szczupłego zarządzania, należy w taki sposób magazynować materiały potrzebne w procesie produkcji, żeby minimalizować zbędny transport i oczekiwanie. Filozofia Lean Management odnosi się też do efektywnego wykorzystania ich potencjału i redukcji zbędnych ruchów.

Narzędzia Lean Management wykorzystywane do usprawnienia procesu produkcji to:

- Mapowanie procesów - stworzenie wizualnego schematu procesów, które należy wykonać.

- TPM (Optymalne Utrzymanie Ruchu) - utworzenie działu, którego zadaniem jest niezwłoczne usuwanie awarii i błędów systemowych. Do jego zadań należy także udoskonalanie wykorzystywanych maszyn.

- SMED - redukcja czasu potrzebnego do przezbrojenia maszyn. Pozwala na tworzenie elastycznych procesów wytwarzania i zarządzania oraz modyfikuje proces produkcji. SMED może być używany do zmniejszenia wielkości wytwarzanych serii.

- 5S - system uporządkowania firmy, którego elementy składowe przedstawiono w tabeli 1.

Tabela 1. System $5 \mathrm{~S}$

\begin{tabular}{|l|l|}
\hline Nazwa procesu & \multicolumn{1}{c|}{ Opis procesu } \\
\hline Selekcja & Eliminacja niepotrzebnych rzeczy ze stanowiska \\
\hline Systematyka & Zorganizowanie przestrzeni roboczej w celu ułatwienia korzystania z niej \\
\hline Sprzątanie & $\begin{array}{l}\text { Dbałość o porządek na stanowisku, zwiększenie bezpieczeństwa podczas } \\
\text { pracy }\end{array}$ \\
\hline Standaryzacja & Realizacja identycznego procesu na każdym ze stanowisk \\
\hline Samodyscyplina & Utrzymanie systemu przez realizację czterech poprzednich zasad \\
\hline
\end{tabular}

Źródto: opracowanie własne na podstawie Golińska, 2012: 248-249.

Wykorzystanie metody Lean Management pozwala podnosić zadowolenie klientów przez oferowanie im zróżnicowanego asortymentu o wysokiej jakości. Sprostanie wymaganiom klientów buduje zaufanie do przedsiębiorstwa, co przekłada się na wzrost popytu na oferowane przez nie dobra przy ceteris paribus.

Metodę Lean można stosować również w pozostałych gałęziach logistyki (dystrybucji, obsłudze zwrotów), a także w procesie recyklingu, aby zminimalizować poziom odpadów i ponownie móc ich użyć w procesie produkcji. 


\subsection{Logistyka dystrybucji}

Przedsiębiorstwa powinny starać się zarządzać transportem, dystrybucją oraz magazynowaniem w taki sposób, aby jak najefektowniej dostarczać wyroby gotowe konsumentom. Proces dystrybucji wiąże się z czynnościami pokonywania odległości przestrzennych, czasowych, ilościowych i asortymentowych. Ma za zadanie koordynować, czyli zrównoważyć popyt z podażą. Obejmuje czynności takie jak zbieranie i przekazywanie producentom informacji o potencjalnym kliencie. Proces dystrybucji zajmuje się organizacją transportu oraz magazynowania. Lean Management ma za zadanie ograniczyć błędy i poprawić zarządzanie zapasami oraz podnieść poziom i jakość obsługi klienta. Kluczem do podniesienia satysfakcji odbiorców końcowych jest usprawnienie przepływu wyrobów gotowych oraz bezzwłoczna reakcja na ich potrzeby. Przy użyciu narzędzi i metod Lean Management przedsiębiorstwo minimalizuje koszty transportu oraz zapasów.

Narzędzia i metody wykorzystywane do usprawnienia procesu dystrybucji to:

- Łańcuch dostaw zorientowany na klienta (ang. Efficient Consumer Response) - nowoczesna strategia dystrybucji zorientowana na integrację w jednym łańcuchu dostaw producentów, dystrybutorów oraz handlowców. Celem strategii jest skrócenie czasu wykonania zamówienia poprzez zmniejszenie czasu przepływu zapasów. Przy pomocy innowacyjnych metod zarządzania oraz technologii ma za zadanie podnieść poziom i jakość obsługi klienta z jednoczesnym obniżeniem kosztów i zapasów.

- Quick Response - koncepcja zarządzania skoncentrowana na zwiększeniu zadowolenia klienta oraz skróceniu czasu od otrzymania zamówienia do dostawy produktów. Ma za zadanie szybko i sprawnie reagować na sytuację rynkową.

- Klasyfikacja ABC - optymalizacja czasu kompletacji, poprzez klasyfikację zasobów według malejącej wartości bądź innego wskaźnika. Podział zasobów na trzy klasy: A, B, C. Klasa A zawiera pozycje, które potrzebują najwięcej uwagi oraz są najdroższe. Klasa B - zasoby o mniejszej wartości. Klasa C obejmuje pozostałe zasoby.

- Wizualizacja stanu magazynu - wspomaga zarządzanie przestrzenią magazynowania. Przy pomocy tego oprogramowania można zobaczyć aktualny stan zajętości magazynu, automatycznie podpowiada, gdzie może być składowany towar. Zmniejsza to czas oraz wysiłek w pracy.

\subsection{Logistyka odzysku}

Logistyka zwrotna obejmuje przepływy uszkodzonych i zużytych produktów oraz towarzyszącej im informacji od miejsca, w którym uszkodzenia powstały, do zakładu, w którym te produkty zostaną przetworzone bądź zutylizowane. Istotnym 
zadaniem tego ogniwa łańcucha dostaw jest minimalizowanie szkodliwego wpływu odpadów na środowisko naturalne.

Już na etapie zbiórki odpadów można wprowadzić regulacje mające na celu usprawnienie działania całego łańcucha dostaw oraz zmniejszyć poziom negatywnego oddziaływania na środowisko naturalne, gospodarkę i społeczeństwo. Stosowanie selektywnego systemu zbiórki odpadów przynosi korzyści gospodarce, ponieważ minimalizuje koszty przetwarzania zwrotów, w dodatku kształtuje pozytywne postawy społeczne.

Odpady mogą być poddane utylizacji, użyte ponownie lub składowane. Składowanie jest sprzeczne z zasadami Lean Management, dlatego dążyć się powinno do maksymalnego wykorzystania produktów, które są przedmiotem logistyki zwrotnej, jako surowców do produkcji nowych dóbr. Składowanie odpadów można przeprowadzić jedynie w przypadku dóbr, których nie da się w żaden sposób przetworzyć.

Wyszczuplanie procesu odzysku powinno obejmować również zastosowanie zasad Lean Management w transporcie odpadów. Należy zoptymalizować trasy, aby zminimalizować liczbę niepotrzebnie przejechanych kilometrów, liczbę pustych przejazdów, a także tych przejechanych z wolną przestrzenią ładunkową.

W zależności od potrzeb danego przedsiębiorstwa można dokonać wyboru wariantu wywozu odpadów. Najczęściej stosowany jest system jednostopniowy, polegający na transporcie odpadów bezpośrednio z miejsca ich wytworzenia do zakładu, w którym będą przetwarzane lub magazynowane. System dwustopniowy wykorzystuje dodatkową infrastrukturę w postaci stacji przeładunkowej, w której odpady są czasowo magazynowane.

Logistyka zwrotna obejmuje również zarządzanie zwrotnymi przepływami opakowań. Zazwyczaj optymalne jest używanie opakowań zwrotnych, które po ich umyciu i ewentualnych naprawach mogą być ponownie użyte. Jeśli chodzi o opakowania jednorazowe, to mogą one być magazynowane lub poddane utylizacji.

\section{Podsumowanie}

Reasumując, Lean Management jest koncepcją zarządzania przedsiębiorstwem, skłaniającą się do redukcji marnotrawstwa w poszczególnych procesach. Szczupłe zarządzanie jest wykorzystywane w różnych gałęziach przemysłu i usług. Stosując Lean w zrównoważonym łańcuchu dostaw, przedsiębiorstwo buduje lojalność oraz zadowolenie wśród finalnych odbiorców poprzez natychmiastową reakcję na potrzeby klienta. Używając narzędzi Lean Management, przedsiębiorstwo redukuje czas oraz koszty produkcji. Przepływ materiałów jest ciągły, co doprowadza 
do tworzenia produktów i usług bez wad i zakłóceń, zwiększenia wydajności. Koncepcja ta ma jednak pewne minusy, które są widoczne u pracowników. Stres, brak motywacji to tylko niektóre przejawy widoczne wśród pracujących. Pomimo wad Lean Management przynosi wiele pozytywnych efektów w strukturze przedsiębiorstwa.

\section{Bibliografia}

Golińska P. (red.), (2012), Lean Management w produkcji i logistyce, Wydawnictwo Politechniki Poznańskiej, Poznań.

Harrison A., van Hoek R., (2010), Zarzq̨dzanie logistykq, Polskie Wydawnictwo Ekonomiczne, Warszawa.

\section{Źródta internetowe}

http://odpowiedzialnybiznes.pl/publikacje/analiza-tematyczna-zrownowazony-lancuchdostaw-trendy-i-innowacje/ [dostęp 11.03.2016].

http://www.czasopismologistyka.pl/artykuly-naukowe/send/-/67 [dostęp 11.03.2015].

http://www.czasopismologistyka.pl/artykuly-naukowe/send/318-artykuly-na-plycie-cd-3/6307-artykul [dostęp 28.03.2015].

http://www.logistyka.net.pl/bank-wiedzy/logistyka/item/85904-logistyka-zwrotna-zrodlemzwiekszania-konkurencyjnosci-firm-w-lancuchach-dostaw [dostęp 28.03.2015]. 